\title{
Age and origin of groundwater resources in the Ararat Valley, Armenia: a baseline study applying hydrogeochemistry and environmental tracers
}

\author{
Michael Schubert ${ }^{1} \cdot$ Nils Michelsen $^{2} \cdot$ Axel Schmidt $^{3} \cdot$ Laura Eichenauer $^{2} \cdot$ Kay Knoeller $^{4} \cdot$ Alexander Arakelyan $^{5}$. \\ Lilith Harutyunyan $^{6}$. Christoph Schüth ${ }^{2}$ (B)
}

Received: 24 November 2020 / Accepted: 27 July 2021 / Published online: 28 August 2021

(C) The Author(s) 2021

\begin{abstract}
Within the Ararat Valley (Armenia), a continuously growing water demand (for irrigation and fish farming) and a simultaneous decline in groundwater recharge (due to climate change) result in increasing stress on the local groundwater resources. This detrimental development is reflected by groundwater-level drops and an associated reduction of the area with artesian conditions in the valley centre. This situation calls for increasing efforts aimed at more sustainable water resources management. The aim of this baseline study was the collection of data that allows for study on the origin and age distribution of the Ararat Valley groundwater based on environmental tracers, namely stable $\left(\delta^{2} \mathrm{H}, \delta^{18} \mathrm{O}\right)$ and radioactive $\left({ }^{35} \mathrm{~S},{ }^{3} \mathrm{H}\right)$ isotopes, as well as physical-chemical indicators. The results show that the Ararat Valley receives modern recharge, despite its (semi-)arid climate. While subannual groundwater residence times could be disproved $\left({ }^{35} \mathrm{~S}\right.$ ), the detected ${ }^{3} \mathrm{H}$ pattern suggests groundwater ages of several decades, with the oldest waters being recharged around 60 years ago. The differing groundwater ages are reflected by varying scatter of stable isotope and hydrochemical signatures. The presence of young groundwater (i.e., younger that the 1970s), some containing nitrate, indicates groundwater vulnerability and underscores the importance of increased efforts to achieve sustainable management of this natural resource. Since stable isotope signatures indicate the recharge areas to be located in the mountains surrounding the valley, these efforts must not be limited to the central part of the valley where most of the abstraction wells are located.
\end{abstract}

Keywords Groundwater residence time $\cdot$ Tritium $\cdot$ Radiosulphur $\cdot$ Stable isotopes $\cdot$ Armenia

Christoph Schüth

schueth@geo.tu-darmstadt.de

1 UFZ - Helmholtz Centre for Environmental Research, Permoserstr. 15, 04318 Leipzig, Germany

2 Technical University of Darmstadt, Institute of Applied Geosciences, Schnittspahnstr. 9, 64287 Darmstadt, Germany

3 BfG - Bundesanstalt für Gewässerkunde, Am Mainzer Tor 1, 56068 Koblenz, Germany

4 UFZ - Helmholtz Centre for Environmental Research, Theodor-Lieser-Str. 4, 06120 Halle, Germany

5 IGS of NAS RA / American University of Armenia, 24a M. Baghramyan ave, 0033 Yerevan, Armenia

6 USAID ASPIRED Project, 105/1 Teryan St., Suite 204, 0009 Yerevan, Armenia

\section{Introduction}

Due to growing globalization and the impacts of recent regional conflicts, the southern Caucasus region (i.e., Armenia, Azerbaijan, and Georgia) becomes increasingly relevant from the geopolitical perspective. Regional food safety is one of the key issues in this regard and major attention is therefore drawn to the continuously growing water demand and the sustainable management of the regional water resources.

In addition, climate change is expected to have an impact on the renewable water resources in the region, potentially further complicating the situation into the future. Long-term records of the mean annual temperature in Armenia reveal an increase of about $1.23^{\circ} \mathrm{C}$ for the period $1929-2016$, relative to the reference period 1961-1990 (Aslanyan and Harutyunyan 2020). Moreover, climate modelling focusing on the growing season (April-October) in the period 2011-2040 indicated temperature increases of $1.60{ }^{\circ} \mathrm{C}$ (scenario RCP 4.5) and $1.9^{\circ} \mathrm{C}$ (scenario RCP 8.5), relative to the period 1971-2000 (Melkonyan 2014). 
The UN Intergovernmental Panel on Climate Change expects this development to be complemented by decreasing precipitation rates, reflected in a precipitation decline of between 10 and $20 \%$ by the end of the twenty-first century in the overall southern Caucasus region (IPCC 2014). For Armenia, a decline of 9\% was found for the period 1935-2016, relative to the period 1961-1990 (Aslanyan and Harutyunyan 2020). As a result, Armenian river flow is predicted to drop by $24 \%$ by the end of the century, accompanied by a significant depletion of the regional groundwater resources (SEI 2009). Climatic changes will also lead to a substantial increase in irrigation water demand. Yet, in view of the predicted decline in water resources, this demand will be difficult to meet, possibly causing a $15-34 \%$ productivity reduction of irrigated cropland (Yu et al. 2015).

The most important agricultural area in Armenia and also the country's main area for fish farming is the Ararat Valley located in the country's southwest ( $\mathrm{Yu}$ et al. 2015). For fishery purposes only, the Armenian Ministry of Nature Protection issued permits for 576 wells with a total discharge rate of approximately $43,200 \mathrm{~L} / \mathrm{s}$ (Valder et al. 2018). This discharge rate greatly exceeds the recharge rate of the renewable groundwater resources, as the Ararat Valley is the most arid region of Armenia with an annual precipitation of about 200-250 mm only (Nalbandyan 2012; Valder et al. 2018). As a result of this ongoing groundwater overabstraction, groundwater levels within the valley decreased on average by 6-9 m between 1983 and 2013 ( $\mathrm{Yu}$ et al. 2015). Furthermore, the artesian zone within the valley has reduced from about 619 to $291 \mathrm{~km}^{2}$ between 1984 and 2016 (Valder et al. 2018) and artesian well discharges have reduced by up to $200 \mathrm{~L} / \mathrm{s}$ ( $\mathrm{Yu}$ et al. 2015). In contrast, the crop water requirement in the Ararat Valley is expected to increase by about $20 \%$ by the end of the twenty-first century, resulting in a growth of the irrigation water demand by about $35 \%$ (Westphal 2011).

As a consequence of the recent situation and the projected future development, new strategies that allow a sustainable management of the natural water resources in the Ararat Valley are necessary. This in turn requires an adequate understanding of the hydrogeological situation in the Ararat Valley, with particular focus on groundwater recharge and groundwater residence times (i.e., "groundwater age"). The aim of the baseline study reported in this paper was to collect reference data on the origin and age of Ararat Valley groundwater resources using environmental aqueous tracers, namely stable $\left(\delta^{2} \mathrm{H}, \delta^{18} \mathrm{O}\right)$ and radioactive $\left({ }^{35} \mathrm{~S},{ }^{3} \mathrm{H}\right)$ isotopes, as well as a set of physical-chemical indicators.

\section{Materials and methods}

\section{Study area}

The Ararat Valley is a Cenozoic basin south of the Lesser Caucasus, shared by the countries Armenia and Turkey (Fig. 1a). Elevations within the valley range from 800 to $900 \mathrm{~m}$ asl, with the lowest elevations in the southeast and the highest in the northwest. The valley occupies an area of about $1,300 \mathrm{~km}^{2}$ (ME\&A, Armenian branch 2014). The Araks River divides the Ararat Valley into a northern and a southern part. The northern part belongs to Armenia and contains the study area.

From a hydrogeological perspective, the Ararat Valley is a typical closed intermountain artesian basin. The major watercourses are the Araks River and its tributaries. Generally, the basin is characterized by a high heterogeneity of lithological and hydrogeological parameters. The strongly variable components, in particular, are (1) thickness and composition of the different lithological units, (2) hydraulic conductivities of the different aquifer domains, and (3) groundwater temperature and mineralization. This overall heterogeneity is due to the fact that the entire basin was divided by folding into five substructures (ME\&A, Armenian branch 2014).

In spite of this heterogeneous structure, the subsurface succession can be subdivided into nine lithological units. These mainly consist of interbedded dense clays, gravels, sands, basalts, and andesite deposits. Four of the nine units are considered to be water-bearing. While the upper water-bearing unit 2 is unconfined, the lower three water-bearing units $(4,6,8)$ are confined, due to a clay layer or sandy clay with an average thickness of $14 \mathrm{~m}$ between units 2 and 4 (Valder et al. 2018; Fig. 1b).

The upper unconfined aquifer has a mean thickness of $32 \mathrm{~m}$ and consists of alluvial deposits, primarily boulder or gravel deposits with coarse-grained sand, sandy clay, or clay. The three confined aquifers, units 4,6 and 8 , have average thicknesses of 27,17 , and $23 \mathrm{~m}$, respectively. While unit 4 has a similar sedimentological setup as unit 2, units 6 and 8 are mainly characterized by highly fractured basalt, as well as gravel deposits with coarse grained-sand and boulders. The heterogeneous nature of the depositional environments is also reflected by the maximum thicknesses of the units, which are $89 \mathrm{~m}$ for unit 2, and 110,148, and $119 \mathrm{~m}$ for units 4, 6 and 8 , respectively (Valder et al. 2018). The reported hydraulic conductivities of these units also show appreciable variability. They range from about $1 \mathrm{~m} /$ day to about $150 \mathrm{~m} /$ day in the

Fig. 1 a Map of the study area showing the sampled wells. Out of the 28 wells, 26 (W03-W28) are located within the Ararat Valley (Armenian part). The valley boundary is represented by the $900 \mathrm{~m}$ asl contour line (white line). Parts of the valley are used for fish farming (blue hatched areas; ACE 2020). b Hydrogeological cross-section of the valley (Valder et al. 2018, modified) 

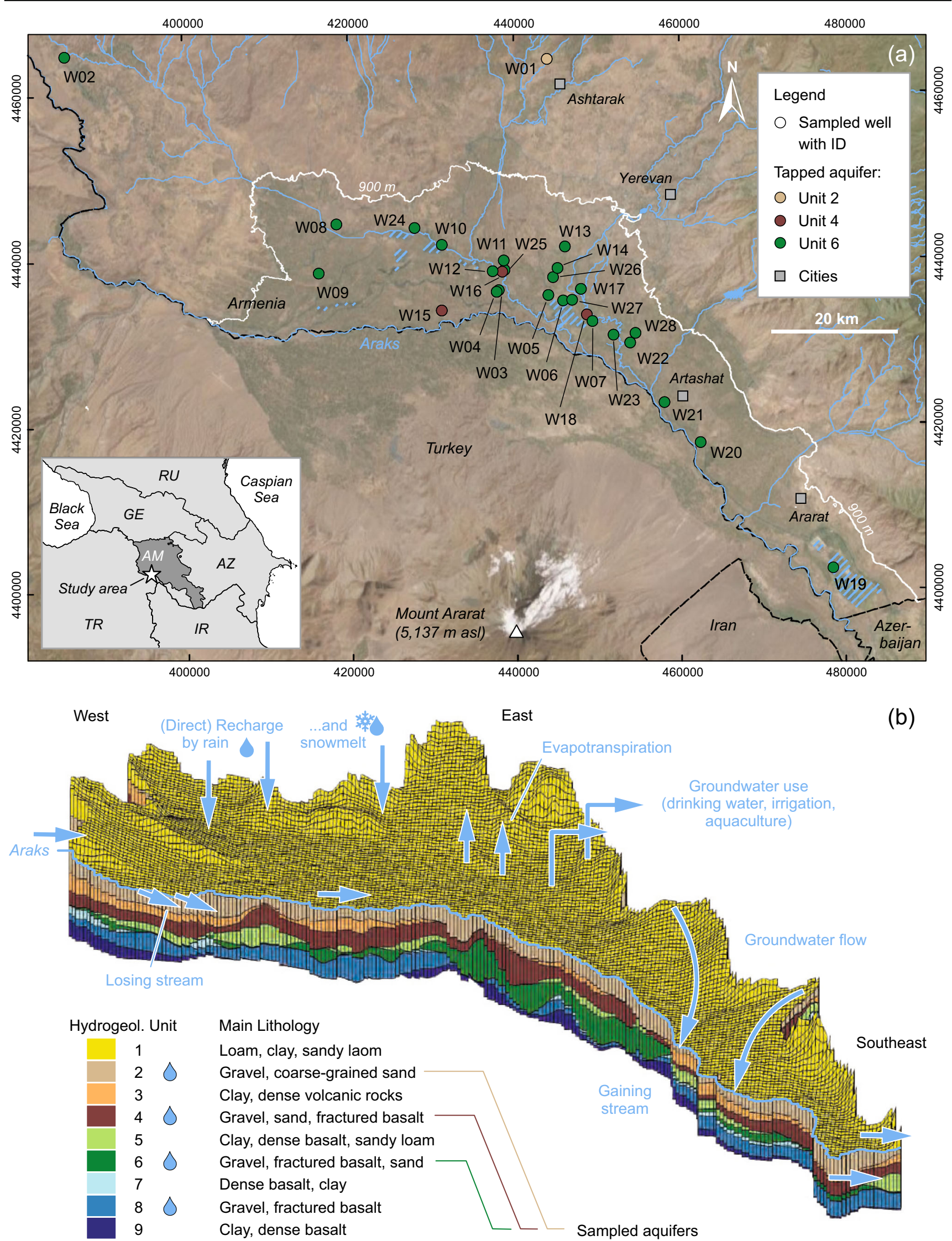
unconfined unit 2, and from about $0.9 \mathrm{~m} /$ day to about $115 \mathrm{~m} /$ day in the three confined units (ME\&A, Armenian branch 2014).

The general groundwater flow direction coincides with the terrain inclination and is mostly directed towards the central axis of the valley, i.e., the Araks River. The groundwater generally flows northwest to southeast in the western part of the valley and from northeast to southwest in its western part. The paleo-valleys of the Araks tributaries, which are filled with interbedded clays, sands, gravels, basalts, and andesites (Valder et al. 2018), serve as major groundwater migration pathways between the recharge areas in the surrounding mountains (up to $5,137 \mathrm{~m}$ asl) and the centre of the valley. The Araks River itself is a losing stream in the western part of the valley, resulting in a deviating flow direction from south to north in unit 2 in this part of the valley. In the southeast, it is a gaining stream - (Valder et al. 2018; Fig. 1b; Figs. S1-S3 in the electronic supplementary material (ESM)).

The confined aquifers are artesian in the central part of the valley, however, due to the heavy groundwater abstraction many wells have ceased to flow and the area with artesian conditions substantially decreased (ME\&A, Armenian branch 2014; Valder et al. 2018; see also Fig. 3).

\section{Sampling and analyses}

Two sampling campaigns were carried out in the Ararat Valley as part of this study, the first in October and the second in December 2019. In total, 28 wells were sampled (W01W28; for detailed information, see Table S1 of the ESM). Out of these 28 wells, one was located in the unconfined unit 2 (W01) outside of the valley boundaries, three in the confined unit 4 (W15, W16, W18), and the rest in the confined unit 6. Well W02 is also situated outside the valley boundaries (Fig. 1a).

This study focused on revealing the age of groundwater sampled from all 28 wells, based on radioisotope tracer results. Revealing the water age, i.e., the groundwater residence time, is essential for evaluating the vulnerability of the tapped aquifer domains. Furthermore, water age-distribution information can be used to constrain groundwater recharge areas. The conclusions regarding the groundwater origin are backed by stable isotope data, physical-chemical parameters, and chemical characteristics of the water samples.

The groundwater samples taken during the two campaigns were analysed for the radionuclides radiosulphur $\left({ }^{35} \mathrm{~S}\right)$ and tritium $\left({ }^{3} \mathrm{H}\right)$, the stable isotope signatures $\delta^{18} \mathrm{O}$ and $\delta^{2} \mathrm{H}$, the field parameters temperature, electrical conductivity (EC), $\mathrm{pH}$ and $\mathrm{O}_{2}$, as well as a range of ions. The following sections introduce briefly the suitability of the used environmental tracers regarding the aim of the study.

\section{Age of the groundwater}

Radiosulphur $\left({ }^{35} \mathrm{~S}\right)$ Although at least partly artesian, several of the wells in the central part of the valley were known to have elevated nitrate concentrations (Avetisyan and Tadevosyan 2017), which might indicate rather young waters. A suitable approach for investigating the presence of very young groundwater (subannual ages) is the use of ${ }^{35} \mathrm{~S}$ as an age tracer. ${ }^{35} \mathrm{~S}$ is continuously produced in the upper atmosphere by spallation of ${ }^{40} \mathrm{Ar}$. From there it is transferred with the rain to the earth's surface and finally to the groundwater. As soon as the water enters the subsurface, its ${ }^{35} \mathrm{~S}$ activity concentration decreases with a half-life of 87.4 days, which makes ${ }^{35} \mathrm{~S}$ suitable for investigating subannual groundwater residence times (Schubert et al. 2019, 2020).

For ${ }^{35} \mathrm{~S}$ detection, $20-\mathrm{L}$ water samples were taken at five selected wells located along the central axis of the valley (W24-W28). ${ }^{35} \mathrm{~S}$ was (together with total sulphate) extracted from the samples in a local laboratory by means of an adsorption resin. Subsequently, the resin samples were shipped to Germany and analysed for ${ }^{35} \mathrm{~S}$ in the UFZ radionuclide laboratory by low-background liquid scintillation counting (Quantulus GCT 6220; PerkinElmer, Inc., Waltham, MA, USA). The sample preparation and measurement process is described in detail in Schubert et al. (2019).

Tritium $\left({ }^{3} \mathrm{H}\right)$ The radionuclide tritium $\left({ }^{3} \mathrm{H}\right.$, half-life 12.32 years (a)) is used as a tracer in a range of settings, including column experiments (Stephens et al. 1998), and investigation of surface waters (Mundschenk and Krause 1991; Schmidt et al. 2020) and the unsaturated zone (Dincer et al. 1974; Jiménez-Martínez et al. 2013). Yet, its main application is the tracing of young groundwaters (Clark and Fritz 1997; Stadler et al. 2012). While the isotope is continuously formed naturally in the stratosphere by cosmic radiation, thermonuclear bomb tests conducted in the 1950s-1980s (mainly during the so-called "fallout peak" era between the late 1950s and 1963, i.e. prior to the Partial Test Ban Treaty in 1963) triggered a remarkable rise of ${ }^{3} \mathrm{H}$ concentrations in the atmosphere. Since then, washout and decay have caused a drop of atmospheric ${ }^{3} \mathrm{H}$ concentrations, which have now reached natural background levels in most regions (Clark and Fritz 1997; Schmidt et al. 2020).

Samples (1 L each) were distilled and ${ }^{3} \mathrm{H}$ was electrolytically enriched. Concentrations were measured by lowbackground liquid scintillation counting (Quantulus GCT 6220; PerkinElmer, Inc., Waltham, MA, USA) with a detection limit of about $0.08 \mathrm{~Bq} / \mathrm{L}$ at the laboratory for environmental isotopes (LfU) of the BfG. All results are conventionally reported in tritium units (TU). 


\section{Origin of the groundwater}

Stable water isotopes $\left(\delta^{18} \mathrm{O}, \delta^{2} \mathrm{H}\right)$ The stable isotope ratios of oxygen and hydrogen in the water molecule, ${ }^{18} \mathrm{O} /{ }^{16} \mathrm{O}$ and ${ }^{2} \mathrm{H} /{ }^{1} \mathrm{H}$, represent a powerful fingerprinting tool in hydrogeology, complementing water ages. Generally, applications include the assessment of water sources (Schmidt et al. 2011; Stadler et al. 2012), (paleo-)climatic effects (Stadler et al. 2012), recharge elevations (Koeniger et al. 2017), biases of recharge towards a certain season (Jasechko et al. 2014) or precipitation type (Müller et al. 2020), or the estimation of evaporative water losses (Skrzypek et al. 2015).

Stable isotope ratios were measured by Laser Cavity RingDown Spectroscopy (L2130-I; Picarro, Santa Clara, CA, USA) at the LfU (BfG). Results are expressed in per mil $(\%)$ using the conventional $\delta$ notation relative to Vienna Standard Mean Ocean Water (V-SMOW). The external precisions $( \pm 1 \sigma)$, determined by repeated analyses of a control sample, were \pm 0.15 and $\pm 0.6 \%$, for $\delta^{18} \mathrm{O}$ and $\delta^{2} \mathrm{H}$, respectively.

Water chemistry During sampling, field parameters (temperature, $\mathrm{pH}$, electrical conductivity, oxygen content) were measured with field probes (HQ40d, Hach, Loveland, CO, USA). Bicarbonate concentrations were also determined on-site with a field kit (HI775, Hanna Instruments, Woonsocket, RI, USA). Furthermore, two samples were collected at each well in 50-ml polyethylene bottles for ion analyses. These samples were filtered using $0.45 \mu \mathrm{m}$ membrane filters. Samples for cation analyses were acidified by adding concentrated $\mathrm{HNO}_{3}$. All major ions were analysed by ion chromatography (882 compact ICplus equipped with a Metrosep A Supp 5-250 column for anions and a Metrosep C 4-250 column for cations, Metrohm, Herisau, Switzerland) at the Institute of Applied Geosciences of the Technical University of Darmstadt. The precision of the applied method, expressed as relative standard deviation, is better than $\pm 3 \%$. The charge balance errors were typically within $\pm 5 \%$.

\section{Results and discussion}

\section{Age of the groundwater}

\section{Radiosulphur $\left({ }^{35} \mathrm{~S}\right)$}

The ${ }^{35} \mathrm{~S}$ activity analyses of the groundwater samples taken at the wells W24-W28 were solely used as a qualitative indicator for the presence of groundwater with a subannual residence time. It was found that none of the five exemplarily chosen wells produced water with any detectable ${ }^{35} \mathrm{~S}$ activity (see Table S1 of the ESM). Since these five wells are evenly distributed throughout the central part of the valley, the presence of groundwater with a subannual residence time in the confined Ararat Valley aquifer section was found to be unlikely.

\section{Tritium $\left({ }^{3} \mathrm{H}\right)$}

The detected ${ }^{3} \mathrm{H}$ activities range from 0.4 to $22.3 \mathrm{TU}$ (see Table S1 of the ESM). To interpret these values, an input function of historic activity concentrations in precipitation is required. Figure 2 shows ${ }^{3} \mathrm{H}$ activities in rain recorded at stations of the Global Network of Isotopes in Precipitation (GNIP) in Tbilisi (Georgia) and Ankara (Turkey; IAEA/ WMO 2020). Furthermore, the figure illustrates the ${ }^{3} \mathrm{H}$ activities of the groundwater samples taken during the two Ararat Valley field surveys.

The historic ${ }^{3} \mathrm{H}$ data illustrate the anthropogenic input into the atmosphere that occurred as a result of nuclear weapon tests. These tests, primarily conducted in the high-latitude regions of the Northern Hemisphere, introduced large ${ }^{3} \mathrm{H}$ amounts into the atmosphere, resulting in activities in rain above 1,000 TU. Pre-fallout levels of rainwater ranged between 5 and 10 TU (Cossairt 2012). Figure 2 shows further that activities in modern rain have declined to around prefallout levels due to radioactive decay and atmospheric washout. Based on recent data, a current average ${ }^{3} \mathrm{H}$ activity in rain of about 9 TU can be assumed (Schmidt et al. 2020).

Based on Fig. 2, the 28 groundwater samples can be classified in three clusters:

1. A set of two samples, with one showing a low (1 TU), and one sample showing a very low ${ }^{3} \mathrm{H}$ activity $(0.4 \mathrm{TU})$

2. A cluster of nine samples that show elevated ${ }^{3} \mathrm{H}$ activities $(\geq 11 \mathrm{TU})$, significantly above the value typical for recent rainfall

3. A cluster of 17 samples that show somewhat lower ${ }^{3} \mathrm{H}$ activities (1.5-6.4 TU) ranging below the recent input value

Based on the ${ }^{3} \mathrm{H}$ input function and the ${ }^{3} \mathrm{H}$ half-life of 12.32 a (and assuming groundwater piston-flow), the three clusters can be associated to three ranges of approximate water ages: (1) the two wells with the lowest ${ }^{3} \mathrm{H}$ concentrations $(\leq 1 \mathrm{TU}$; yellow symbols in Fig. 2) apparently yield groundwater that was recharged prior to the fallout peak ("prefallout water"), i.e., before roughly 1960 , although for the sample with $1 \mathrm{TU}$ (W21) this is ambiguous, as it is located close to the younger age group; (2) the group of nine wells with the highest values ( $\geq 11 \mathrm{TU}$; green symbols in Fig. 2) show a distinct impact of nuclear weapons testing, suggesting that these groundwaters were recharged during and in the wake of the fallout peak (1960s-1970s); (3) the cluster of 17 wells with lesser indications of anthropogenic ${ }^{3} \mathrm{H}(1.5-6.4 \mathrm{TU}$; blue 
Fig. $2{ }^{3} \mathrm{H}$ activities in precipitation recorded at GNIP stations in Tbilisi and Ankara (grey symbols; precipitationweighted means) and in Ararat Valley groundwater samples (coloured symbols). Coloured lines represent decay lines, allowing an approximate groundwater age estimation

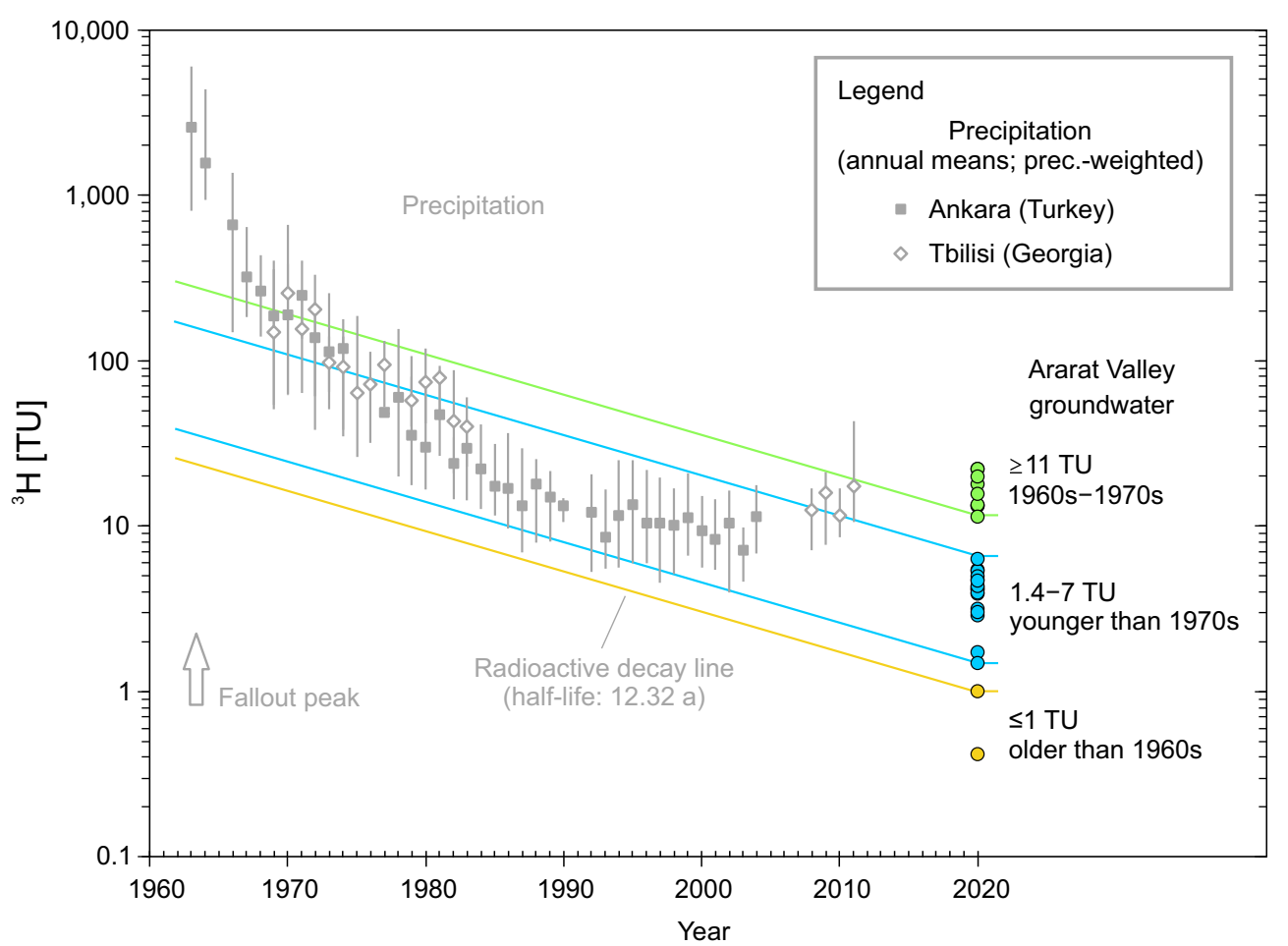

symbols in Fig. 2) seems to indicate younger waters (recharged after the 1970s).

Plotting these water ages in the context of the Ararat Valley reveals a distinct spatial distribution pattern (Fig. $3)$. The apparently oldest water with an age above 60 years was sampled from well W20 (0.4 TU). Its location in the valley is exceptional since it sits on a fault zone (Avagyan et al. 2018) and seems to yield thermal saline water from greater depth. The screened section of this well sits in a depth between 143 and $165 \mathrm{~m}$ in aquifer unit 6 . In contrast to all other wells, which show water temperatures around $14{ }^{\circ} \mathrm{C}$, a temperature of $21.3{ }^{\circ} \mathrm{C}$ was measured at well W20. The electrical conductivity of the water amounts to $5,930 \mu \mathrm{S} / \mathrm{cm}$. Although also quite low in ${ }^{3} \mathrm{H}$ activity, well W21 does not show such distinct differences in temperature and electrical conductivity to the other wells, making an interpretation difficult. Therefore, the further data evaluation concentrates on the distribution of the two age clusters "1960s-1970s" (green symbols in Fig. 3) and "younger than 1970s" (blue symbols in Fig. 3).

The groundwaters with the longer residence times (green symbols) plot near the central axis of the Ararat Valley, clustered in an area of about $15 \times 10 \mathrm{~km}$. The associated nine wells are W03, 05, 06, 11, 12, 14, 16, 25, and 26. In contrast, the wells of the cluster "younger than 1970s" (blue symbols) are located around this "old" cluster and distributed throughout the valley.

\section{Origin of the groundwater}

\section{Stable water isotopes $\left(\delta^{18} \mathrm{O}, \delta^{2} \mathrm{H}\right)$}

The stable water isotope signatures of the Ararat Valley groundwater range from -12.67 to $-9.44 \%$ ofor $\delta^{18} \mathrm{O}$ and from -87.2 to $-64.7 \%$ o for $\delta^{2} \mathrm{H}$ (see Table S1 of the ESM). These values can be compared with the isotopic signature of local precipitation sampled in the town of Artashat (sampled during the 12 months period between July 2014 and June 2015; Brittingham et al. 2019). Artashat is located in the Ararat Valley (see Fig. 1a) at an elevation of about $820 \mathrm{~m}$ asl, i.e., its rain can be assumed to be representative for the central part of the valley. This dataset was used to calculate (1) a mean isotopic composition of local Ararat Valley rain (precipitation-weighted mean for $\delta^{18} \mathrm{O}$ and $\delta^{2} \mathrm{H}$ : -9.24 and $-60.3 \%$, respectively) and (2) a local meteoric water line (LMWL), applying the precipitation-weighted least square regression method (PWLSR) proposed by Crawford et al. (2014; $\delta^{2} \mathrm{H}$ $=7.53 \delta^{18} \mathrm{O}+9.3 \% 0$ ).

All sampled groundwaters plot on or close to this LMWL and slightly above the Global Meteoric Water Line (GMWL) published by Craig (1961; Fig. 4). Hence, the found pattern is consistent with modern recharge. Still, it is worth mentioning that all groundwaters are more depleted in heavy isotopes (i.e., isotopically lighter) than the average rain collected in Artashat (star symbol in Fig. 4). Yet, they are all well within the overall range of the precipitation samples $\left(\delta^{18} \mathrm{O}:-22.45\right.$ to $4.54 \%$; $\delta^{2} \mathrm{H}:-173.5$ to $37.2 \%$; see insert in Fig. 4). Considering the 


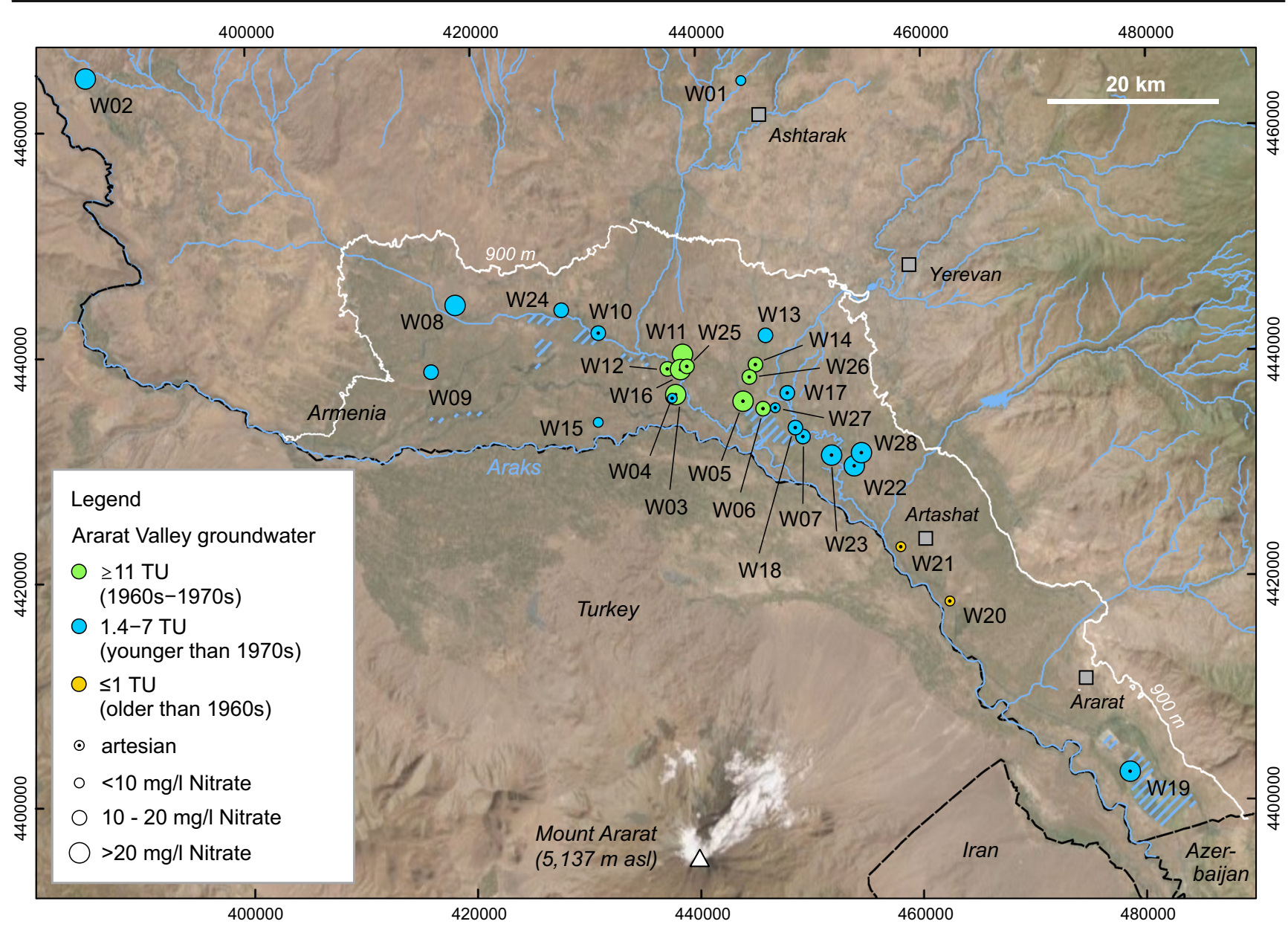

Fig. 3 Lateral ${ }^{3} \mathrm{H}$ distribution pattern with associated water age clusters. The size of the symbols indicates the nitrate concentration of the water (see section 'Water chemistry')

general elevation effect (isotopically lighter precipitation at greater elevation; e.g., -2.6 to $-2.9 \%$ o ${ }^{18} \mathrm{O}$ per $\mathrm{km}$ for the central Anatolian Plateau, Schemmel et al. 2013), this observation points towards groundwater recharge by precipitation occurring in the mountainous areas surrounding the Ararat Valley. This elevation "bias" probably occurs in conjunction with a seasonal bias, since recharge in this region is often associated with the annual snowmelt (Léonardi et al. 1997, 1998, 1999).

Figure 4 also illustrates the scatter of the three ${ }^{3} \mathrm{H}$ clusters discussed in the preceding. The two prefallout groundwater data points (yellow symbols) are difficult to interpret, due to the small number of available samples and the exceptional water origin. Yet, it is worth mentioning that sample W20apparently the oldest water $(0.4 \mathrm{TU})$ - shows the isotopically most depleted signature, indicating old (warm and mineralized) water ascending via the aforementioned fault system from greater depth. The other two ${ }^{3} \mathrm{H}$ clusters scatter over distinctly different $\delta^{18} \mathrm{O}$ and $\delta^{2} \mathrm{H}$ ranges. While the older waters (assumedly recharged in the 1960s and 1970s) show a relatively small spread $\left(\Delta \delta^{18} \mathrm{O}=0.94 \%\right.$ ), the younger ones ("younger than 1970s" cluster) are characterized by a larger spread $\left(\Delta \delta^{18} \mathrm{O}=2.65 \%\right.$; see also Fig. S4 of the ESM). It seems that the samples of the latter cluster preserved the natural isotopic variability, caused by elevation differences and seasonal effects, better than the older cluster. In the older cluster this variability (originally most likely also present) has apparently been levelled out over time.

\section{Water chemistry}

The results of the hydrochemical analyses are presented in Table S1 of the ESM. Temperature and $\mathrm{pH}$ of the sampled wells show an overall homogeneous picture with nearly all values falling in a small range around the median values of $14.2^{\circ} \mathrm{C}$ and 7.0, respectively. Electrical conductivity and oxygen content show wider ranges with median values of $1,041 \mu \mathrm{S} / \mathrm{cm}$ and $7.7 \mathrm{mg} / \mathrm{L}$, respectively.

Well W20, however, does not fit into this overall picture, which underpins the exceptional nature of the water sampled here. The water temperature $\left(21.3^{\circ} \mathrm{C}\right)$ is $7.1^{\circ} \mathrm{C}$ higher than the median of the samples and the electrical conductivity $(5,930 \mu \mathrm{S} / \mathrm{cm})$ is almost six times as high as the median. 
Fig. 4 Stable isotope signatures of the 28 sampled wells. Most groundwaters plot close to the LMWL of Artashat (dashed line; calculated based on data by Brittingham et al. 2019), but are isotopically lighter than the corresponding precipitationweighted mean (star symbol), suggesting recharge at higher elevation, probably preferably during snowmelt

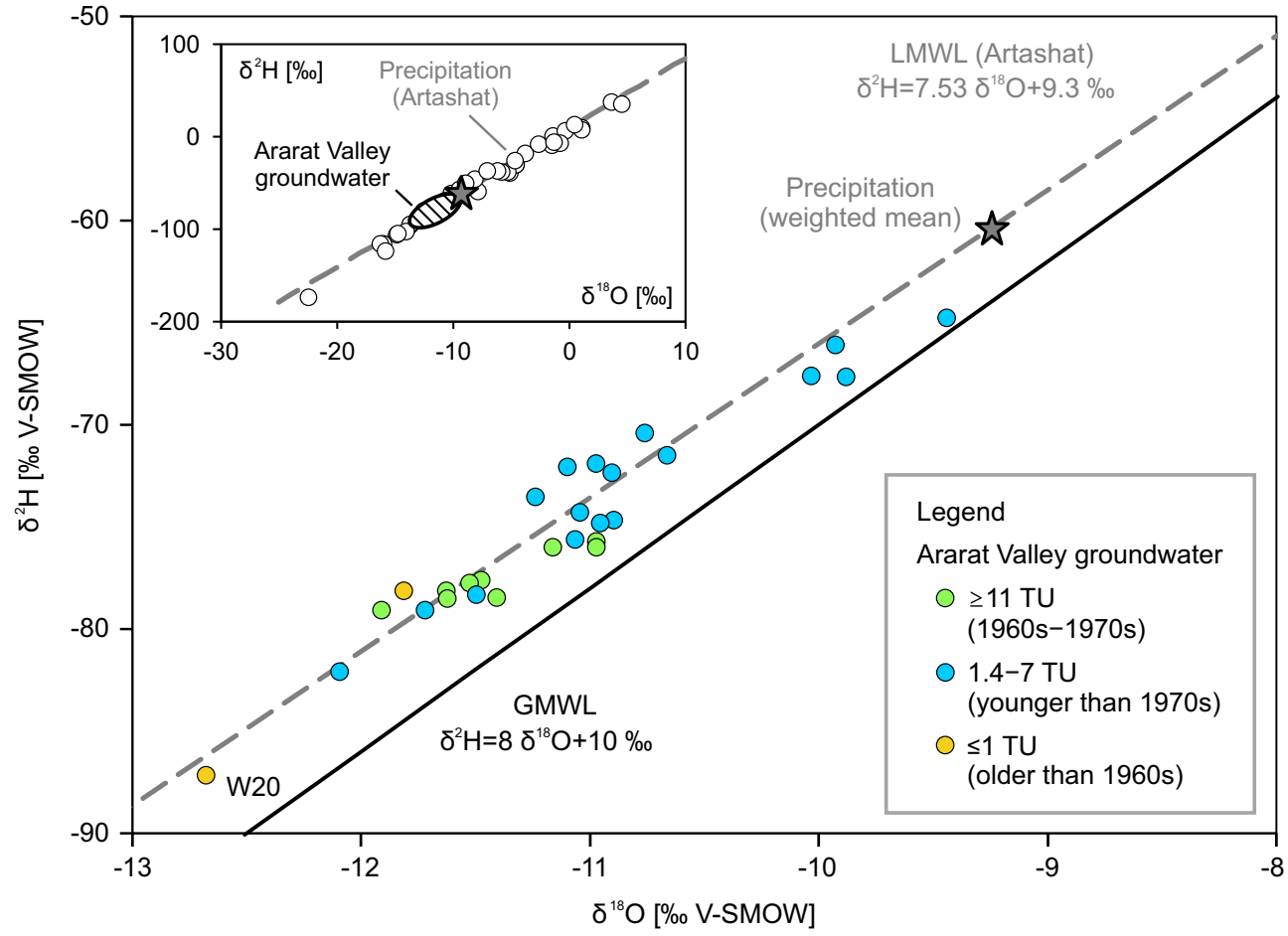

The oxygen content detected in W20 (1.97 $\mathrm{mg} / \mathrm{L})$ is only about a quarter of the corresponding median.

Sample W01, the only sample from the unconfined aquifer unit 2, stands out as well. Here, the lowest water temperature $\left(9.5^{\circ} \mathrm{C}\right)$ and the highest oxygen content $(11.12 \mathrm{mg} / \mathrm{L})$ were encountered, which is attributable to the location of the well.
As mentioned previously, it is not located within the Ararat Valley boundaries, but north of it in a more mountainous area (see Fig. 1), at an elevation of about 1,211 $\mathrm{m}$ asl. The lower annual air temperature prevailing here promotes lower groundwater temperatures and, in turn, causes a higher oxygen solubility.
Fig. 5 Piper plot illustrating the major ion composition of Ararat Valley groundwater. Note the specific chemistry of well W20 and the small scatter of the waters recharged in the 1960s-1970s (green symbols)

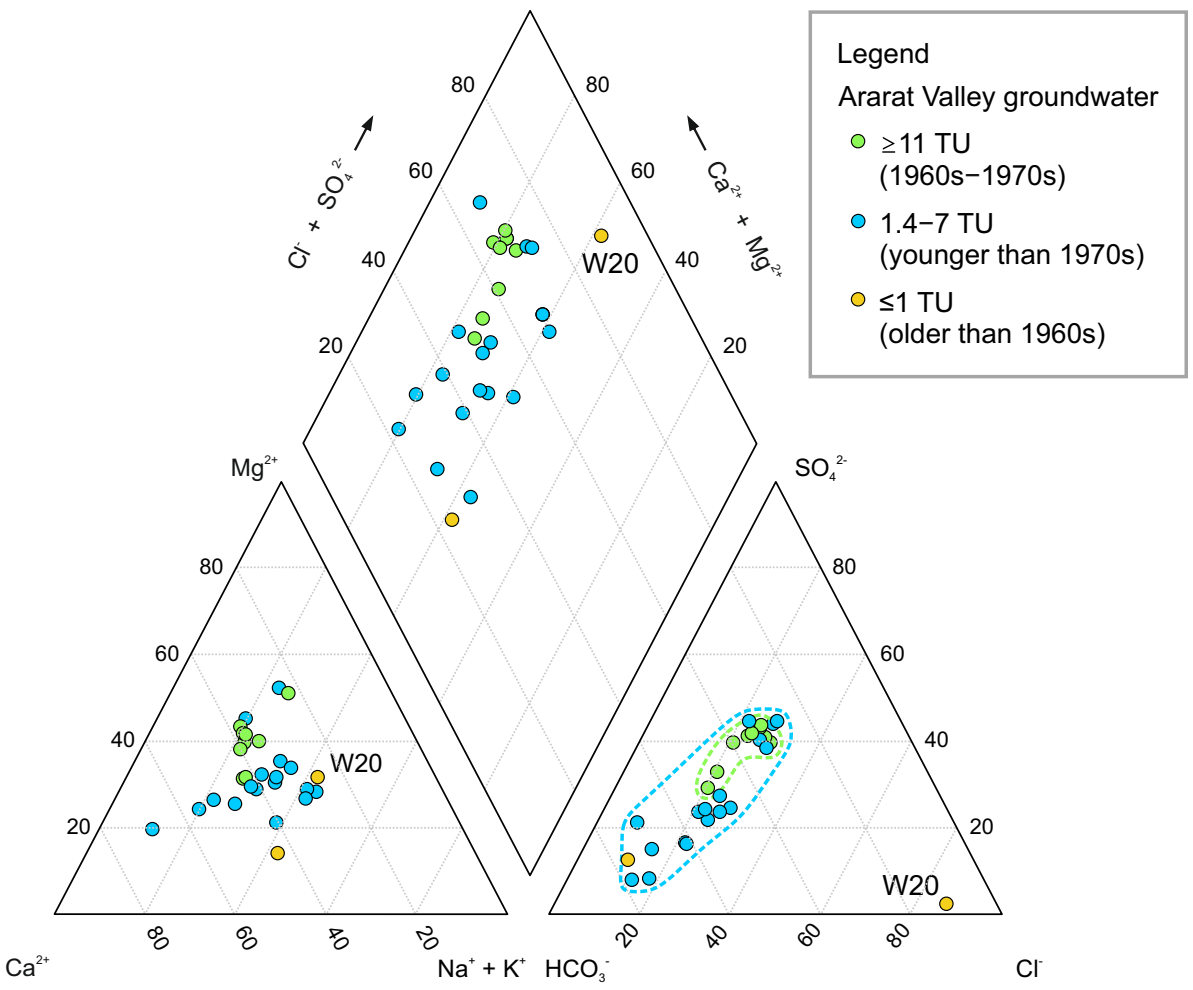


Regarding the major ions, most of the 28 wells show comparable compositions (Fig. 5). In the Piper plot, the cation triangle displays a somewhat balanced composition, with a tendency towards $\mathrm{Ca}^{2+}$ and $\mathrm{Mg}^{2+}$. Regarding the anions, $\mathrm{HCO}_{3}{ }^{-}$dominates, followed by $\mathrm{SO}_{4}{ }^{2-}$. In most samples, $\mathrm{Cl}^{-}$ plays only a minor role. An exception, again, is sample W20, which is dominated by $\mathrm{Cl}^{-}$, which is in line with its highly mineralized character (see also Fig. S5 of the ESM).

Moreover, the limited scatter of the waters recharged in the 1960s-1970s (as indicated by the ${ }^{3} \mathrm{H}$ concentrations) is worth mentioning (dashed green line in Fig. 5). This pattern is in line with the small spread of this group in the $\delta^{2} \mathrm{H}$ versus $\delta^{18} \mathrm{O}$ plot (Fig. 4) and suggests a levelling of chemical (and isotopic) variations with time. In contrast, larger hydrochemical variations (e.g., caused by different lithologies and contact times) have apparently been preserved in the younger waters (blue-dashed line).

This phenomenon is also reflected by the overall mineralization (see also Figs. S6 and S7 of the ESM). While waters recharged in the 1960s-1970s show a fairly small EC range $(722-1,473 \mu \mathrm{S} / \mathrm{cm} ; \Delta \mathrm{EC}=751 \mu \mathrm{S} / \mathrm{cm})$, the younger ones exhibit a larger spread $(263-1,812 \mu \mathrm{S} / \mathrm{cm} ; \Delta \mathrm{EC}=$ $1,549 \mu \mathrm{S} / \mathrm{cm})$.

Moreover, the encountered $\mathrm{NO}_{3}{ }^{-}$concentrations are noteworthy. They range from 2.6 to $39.9 \mathrm{mg} / \mathrm{L}$, with a median of $16.8 \mathrm{mg} / \mathrm{L}$. While none of these concentrations exceeds the WHO (2017) guideline value for drinking water of $50 \mathrm{mg} / \mathrm{L}$, several concentrations are elevated (10 samples $>20 \mathrm{mg} / \mathrm{L}$ ). The spatial nitrate concentration pattern is illustrated in Fig. 3. This map reveals that most of the elevated concentrations were detected in areas that are dominated by fish farming (blue-hatched areas) or agriculture (appearing green on the satellite image). However, in this context one has to keep in mind that the artesian character of some wells (also indicated in Fig. 3) would make anthropogenic contamination originating from recent and adjacent contamination sources unlikely. This is in line with the absence of detectable ${ }^{35} \mathrm{~S}$ activity in the five sampled wells (W24-W28), although they are not located centrally in the fish farming areas. For the aquifer domains with elevated nitrate concentrations, one must rather assume that the corresponding sources are located in the upgradient recharge areas and that the nitrate has been transported over (tens of) kilometres. Pronounced denitrification has apparently been prevented by the available dissolved oxygen (usually several $\mathrm{mg} / \mathrm{L}$, see the preceding and Table S1 of the ESM).

\section{Conclusions}

By using a set of environmental tracers, it was shown that the confined aquifer section of the Ararat Valley receives modern recharge, despite its (semi-)arid climate and partly artesian nature. While the absence of ${ }^{35} \mathrm{~S}$ (activities below the detection limit) in five exemplary and representative wells indicates that subannual groundwater residence times are unlikely throughout the valley, the ${ }^{3} \mathrm{H}$ data suggest groundwater recharge in the last decades. A comparison of the stable isotope signatures $\left(\delta^{18} \mathrm{O}, \delta^{2} \mathrm{H}\right)$ with those of modern precipitation in the valley revealed that the groundwaters are relatively depleted in heavy isotopes. This points towards recharge by precipitation falling in the mountainous areas surrounding the valley. Moreover, a seasonally delayed recharge in the snowmelt period seems likely. The differing groundwater ages, roughly estimated based on the ${ }^{3} \mathrm{H}$ activities, are also reflected by varying degrees of isotopic and hydrochemical scatter.

While modern recharge is usually deemed positive in a water management context, the phenomenon can also have its downsides. Young groundwater generally indicates a nonnegligible aquifer vulnerability (especially in the case of unconfined aquifer domains), with the danger of anthropogenic contamination. In the study area, such contamination was indeed encountered in the form of elevated $\mathrm{NO}_{3}{ }^{-}$concentrations (probably originating from agricultural activities), despite the partly artesian nature of the confined aquifer.

While counter-measures such as a better water and nitrogen management are warranted, one should keep in mind that activities aiming to improve groundwater quality should not be limited to the area adjacent to the concerned wells, but must include the recharge areas at the edges of the valley. As the encountered $\mathrm{NO}_{3}{ }^{-}$is apparently decades old (so-called legacy nitrate), current measures will not lead to an immediate improvement of the situation. Despite the substantial time lag that can be expected (probably several decades), such measures are still worth the effort.

Supplementary Information The online version contains supplementary material available at https://doi.org/10.1007/s10040-021-02390-4.

Acknowledgements We thank Harutyun Yeremyan and Armine Hakobyan (Groundwater Monitoring Service of Hydrometeorology and Monitoring Centre, Ministry of Environment, Armenia) for their assistance in preparing and conducting the field work.

Funding Open Access funding enabled and organized by Projekt DEAL. The study was part of the project TC WaterUse (Travelling Conference "Sustainable Water Resource Management in Regions with Heavily Overexploited Aquifers under Consideration of Regional Impacts of Climate Change") funded by the German Federal Ministry of Education and Research (BMBF).

\section{Declarations}

Conflict of interest There are no conflicts of interest.

Open Access This article is licensed under a Creative Commons Attribution 4.0 International License, which permits use, sharing, adaptation, distribution and reproduction in any medium or format, as long as you give appropriate credit to the original author(s) and the source, 
provide a link to the Creative Commons licence, and indicate if changes were made. The images or other third party material in this article are included in the article's Creative Commons licence, unless indicated otherwise in a credit line to the material. If material is not included in the article's Creative Commons licence and your intended use is not permitted by statutory regulation or exceeds the permitted use, you will need to obtain permission directly from the copyright holder. To view a copy of this licence, visit http://creativecommons.org/licenses/by/4.0/.

\section{References}

ACE (Acopian Center for the Environment) (2020) Vector Database Armenia. American University of Armenia. https://ace.aua.am/vectordatabase-armenia-file-overview/. Accessed 1 November 2020

Aslanyan N, Harutyunyan D (2020) Armenia's 4th National Communication on Climate Change. UNDP Armenia, Yerevan, Armenia, $213 \mathrm{pp}$

Avagyan A, Sosson M, Sahakyan L, Sheremet Y, Vardanyan S, Martirosyan M, Muller C (2018) Tectonic evolution of the northern margin of the Cenozoic Ararat Basin, Lesser Caucasus, Armenia. J Pet Geol 41(4):495-512. https://doi.org/10.1111/jpg.12718

Avetisyan NS, Tadevosyan LH (2017) How to utilize water resources in Ararat artesian basin efficiently simultaneously increasing fish production volumes. Bull Natl Univ Archit Constr Armenia 3:20-25

Brittingham A, Petrosyan Z, Hepburn JC, Richards MP, Hren MT, Hartman G (2019) Influence of the North Atlantic oscillation on $\delta \mathrm{D}$ and $\delta^{18} \mathrm{O}$ in meteoric water in the Armenian Highland. $\mathrm{J}$ Hydrol 575:513-522. https://doi.org/10.1016/j.jhydrol.2019.05.064

Clark ID, Fritz P (1997) Environmental isotopes in hydrogeology. CRC, Boca Raton, FL

Cossairt JD (2012) Environmental protection note no. 28 background levels of tritium. Fermilab, Batavia, IL, pp 2-3

Craig H (1961) Isotopic variations in meteoric waters. Science 133:17021703. https://doi.org/10.1126/science.133.3465.1702

Crawford J, Hughes CE, Lykoudis S (2014) Alternative least squares methods for determining the meteoric water line, demonstrated using GNIP data. J Hydrol 519:2331-2340. https://doi.org/10. 1016/j.jhydrol.2014.10.033

Dincer T, Al-Mugrin A, Zimmermann U (1974) Study of the infiltration and recharge through the sand dunes in arid zones with special reference to the stable isotopes and thermonuclear tritium. J Hydrol 23(1-2):79-109. https://doi.org/10.1016/0022-1694(74)90025-0

IAEA/WMO (International Atomic Energy Agency/World Meteorological Organization) (2020) Global network of isotopes in precipitation. The GNIP Database. http://wwwiaeaorg/water. Accessed 17 September 2020

IPCC (2014) Climate change 2014: synthesis report. In: Pachauri RK, Meyer LA (Core team) (eds) Contribution of Working Groups I, II and III to the fifth assessment report of the Intergovernmental Panel on Climate Change. IPCC, Geneva, Switzerland

Jasechko S, Birks SJ, Gleeson T, Wada Y, Fawcett PJ, Sharp ZD, McDonnell JJ, Welker JM (2014) The pronounced seasonality of global groundwater recharge. Water Resour Res 50(11):8845-8867. https://doi.org/10.1002/2014wr015809

Jiménez-Martínez J, Tamoh K, Candela L (2013) Vadose zone tritium tracer test to estimate aquifer recharge from irrigated areas. Hydrol Process 27:3150-3158. https://doi.org/10.1002/hyp.9441

Koeniger P, Margane A, Abi-Rizk J, Himmelsbach T (2017) Stable isotopebased mean catchment altitudes of springs in the Lebanon Mountains. Hydrol Process 31:3708-3718. https://doi.org/10.1002/hyp.11291

Léonardi V, Arthaud F, Tovmassian A, Karakhanian AS (1997) Relationships between seismic activity and piezometric level changes in the Arax basin (SW Armenia): attempt at a typology of seismically induced piezometric anomalies. Tectonophysics 273 : 293-316. https://doi.org/10.1016/S0040-1951(96)00278-8

Léonardi V, Arthaud F, Tovmassian A, Karakhanian A (1998) Tectonic and seismic conditions for changes in spring discharge along the Garni right lateral strike slip fault (Armenian upland). Geodin Acta 11(2-3):85-103. https://doi.org/10.1016/S0985-3111(98)80007-7

Léonardi V, Kharatian K, Igumnov V, Travi Y (1999) Variations d'origine sismique de la piézométrie, de I'hydrochimie et de l'émission d'hélium dans des réservoirs artésiens en Arménie [Seismic variations in piezometry, hydrochemistry and helium emission in artesian reservoirs in Armenia]. C R Acad Sci Sci Terre Planèts 328(1):51-58. https://doi.org/10.1016/S1251-8050(99) 80087-1

ME\&A (Mendez England and Associates) (2014) Assessment study of groundwater resources of the Ararat Valley: final report. Consortium of Hayjrnakhagits Institute CJSC and Mel-Hov LLC within the USAID-funded Clean Energy and Water Program, Hayjrnakhagits, Yerevan, Armenia

Melkonyan A (2014) Environmental and socio-economic vulnerability of agricultural sector in Armenia. Sci Total Environ 488-489:333-342. https://doi.org/10.1016/j.scitotenv.2014.03.126

Müller T, Friesen J, Weise SM, Al Abri O, Bait Said ABA, Michelsen N (2020) Stable isotope composition of cyclone Mekunu rainfall, southern Oman. Water Resour Res 56(12):e2020WR027644. https://doi.org/10.1029/2020wr027644

Mundschenk H, Krause WJ (1991) Behaviour and radiological significance of tritium from nuclear power plants and other sources in the Rhine river basin. J Environ Radioact 14(4):341-360. https://doi. org/10.1016/0265-931x(91)90024-a

Nalbandyan M (2012) Management and perspectives of using of underground freshwaters from transboundary aquifers in Armenia. SGEM2012 conference proceedings, Bulgaria, June 17-23, 2012 3:769-776

Schemmel F, Mikes T, Rojay B, Mulch A (2013) The impact of topography on isotopes in precipitation across the central Anatolian plateau (Turkey). Am J Sci 313(2):61-80. https://doi.org/10.2475/02. 2013.01

Schmidt A, Santos IR, Burnett WC, Niencheski F, Knoeller K (2011) Groundwater sources in a permeable coastal barrier: evidence from stable isotopes. J Hydrol 406(1-2):66-72. https://doi.org/10.1016/j. jhydrol.2011.06.001

Schmidt A, Frank G, Stichler W, Duester L, Steinkopff T, Stumpp C (2020) Overview of tritium records from precipitation and surface waters in Germany. Hydrol Process 34(6):1489-1493. https://doi. org/10.1002/hyp.13691

Schubert M, Kopitz J, Knöller K (2019) Improved approach for LSC detection of ${ }^{35} \mathrm{~S}$ aiming at its application as tracer for short groundwater residence times. J Environ Radioact 208-209:106022. https:// doi.org/10.1016/j.jenvrad.2019.106022

Schubert M, Kopitz J, Knöller K (2020) Low-sulphate water sample preparation for LSC detection of ${ }^{35} \mathrm{~S}$ avoiding sulphate precipitation. J Environ Radioact 213:106153. https://doi.org/10.1016/j.jenvrad. 2019.106153

SEI (Stockholm Environment Institute) (2009) The socio-economic impact of climate change in Armenia. UNDP, Yerevan, Armenia, $136 \mathrm{pp}$

Skrzypek G, Mydłowski A, Dogramaci S, Hedley P, Gibson JJ, Grierson PF (2015) Estimation of evaporative loss based on the stable isotope composition of water using Hydrocalculator. J Hydrol 523:781789. https://doi.org/10.1016/j.jhydrol.2015.02.010

Stadler S, Geyh MA, Ploethner D, Koeniger P (2012) The deep cretaceous aquifer in the Aleppo and steppe basins of Syria: assessment of the meteoric origin and geographic source of the groundwater. Hydrogeol J 20:1007-1026. https://doi.org/10.1007/s10040-012-0862-2

Stephens DB, Hsu KC, Prieksat MA, Ankeny MD, Blandford N, Roth TL, Kelsey JA, Whitworth JR (1998) A comparison of estimated 
and calculated effective porosity. Hydrogeol J 6(1):156-165. https:// doi.org/10.1007/s100400050141

Valder JF, Carter JM, Medler CJ, Thompson RF, Anderson MT (2018)

Hydrogeologic framework and groundwater conditions of the Ararat Basin in Armenia. US Geol Surv Sci Invest Rep 2017-5163, 40 pp. https://doi.org/10.3133/sir20175163

Westphal MI (2011) Regional climate change impacts study for the South Caucasus region. Report, United Nations Development Programme, New York City, 62 pp
WHO (World Health Organization) (2017) Guidelines for drinking-water quality, 4th edn. WHO, Geneva, $541 \mathrm{pp}$

Yu W, Cestti RE, Lee JY (2015) Toward integrated water resources management in Armenia. The World Bank, Washington, DC, 156 pp. https://doi.org/10.1596/978-1-4648-0335-2

Publisher's note Springer Nature remains neutral with regard to jurisdictional claims in published maps and institutional affiliations. 